\title{
Ethnic Bullying: Nineteenth-Century Magyar Education Policies
}

\section{John Braidwood}

University of Oulu, Finland

\section{Introduction}

The cultural, political, educational and historical relationships of the Magyars with their former national minorities are barely known outside the Central and East European region, though they still resonate across today's Hungarian borders, presenting a deeply troubled and contested discourse, with disputed national identities and incompatible narratives of nation at the core of these relationships. The Magyars of the Kingdom of Hungary were once the dominant power in the Carpathian Basin, ruling a disparate group of national minorities, although the Magyars actually formed a ruling minority elite within the Kingdom. For the purposes of clarity in this paper I use Magyar for those of purely 'Hungarian' ethnic identity.

Following the Ottoman occupation (1541-1699) the Magyars came under German-speaking Habsburg rule, causing the Germanisation of Magyar culture, and culminating in the 1848-1849 Hungarian Revolution and War of Independence; this in turn resulted in the Ausgleich (kiegyezés, or Compromise) of 1868, which gave the Magyars de facto autonomy over the lands of the Carpathian Basin. The nineteenth century saw a decisive resurgence of Magyar identity and one of the key pillars of this was the Magyarization of the national minorities, to be achieved in large part through 'enlightened' education policies pursued by the ruling Magyar minority.

A current OECD document is wholly uncritical of these frankly tyrannical policies, which also came to be known as 'grünwaldizmus' after the rabidly nationalistic Magyar MP Béla Grünwald (1839-1891). This paper seeks to challenge the supposedly enlightened education policies of the Magyars by looking at them from a different angle, particularly the Slovak one. The cultural belligerence of the Magyars brought the Kingdom of Hungary into international disrepute and set it on the road to the Treaty of Trianon (4 June 1920) and subsequent dismemberment; their militant stance is extremely provocative and 
has led to an endless "rhetoric of confrontation" (Chmel, 2006) in the region. This paper will draw on a wide range of sources, including both Hungarian and Slovak ones, as well as the great Anglo-Scottish graphomaniac pioneer and champion of minority rights within the Hungarian Kingdom, Robert William Seton-Watson, also known by the pseudonym Scotus Viator.

Seton-Watson played a prominent role in establishing a School of Slavonic Studies at Kings College, London in 1915 (later becoming the School of Slavonic and East European Studies). The research carried out in this paper will, it is hoped, provide a unique insight into (un)enlightened education policies carried out by the Magyars and will contribute to the discussion on novel ideas in education taking place on the fringes of the Russian Empire in the nineteenth and into the early twentieth centuries.

\section{The scene: geographical and legal boundaries}

Not far from the National Gallery in Bratislava is the Old Town (Staré Mesto) and nearby a small square called Rudnayovo námestie with the Cathedral of Saint Martin (Dóm Sv. Martina in Slovak), which was the coronation cathedral of Magyar monarchs from 1536 to 1830. During the long Ottoman occupation of Hungary, and up until 1848, Pozsony-as Bratislava is called in Hungarianwas the capital of Hungary. This is quite an overlap in national identity narratives and it certainly marks out one of the key reasons for the Magyars' particular sense of loss felt with regard to Slovakia. The cathedral, even today, has a copy of the Hungarian coronation crown atop its spire. Turning away from the cathedral towards the little square, there is a large plaque on the wall of a building opposite which tells a rather unsettling story regarding these Magyars. The plaque commemorates the deportations of Slovak children to Magyar-majority lands within the kingdom for re-education and denationalization.

It may be initially confusing to discover the coronation cathedral of Magyar monarchs in the Slovak capital but this plaque commemorating a real Pied Piper, not of Hamelin as in the well-known fairy tale, but of Slovakia, is baffling to the uninitiated. The Piper, of course, was the Magyar. 


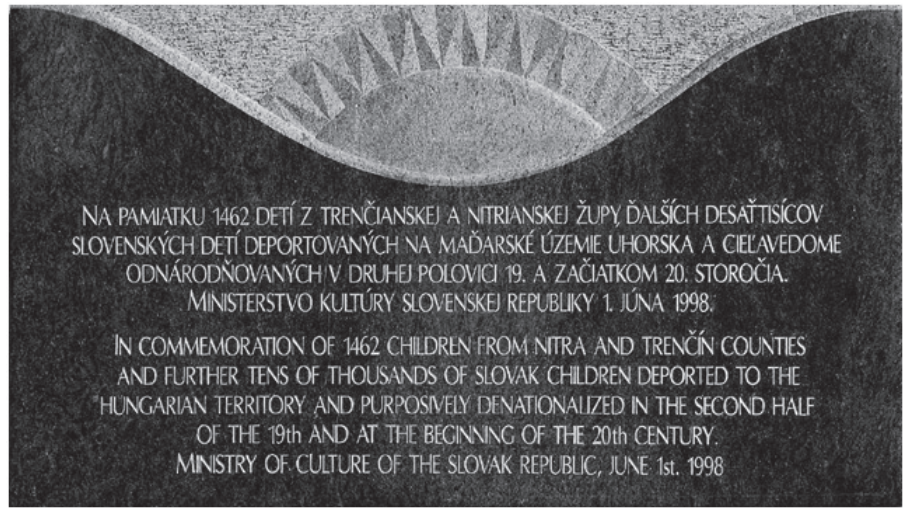

Figure 1. Plaque commemorating the deportations, Bratislava1

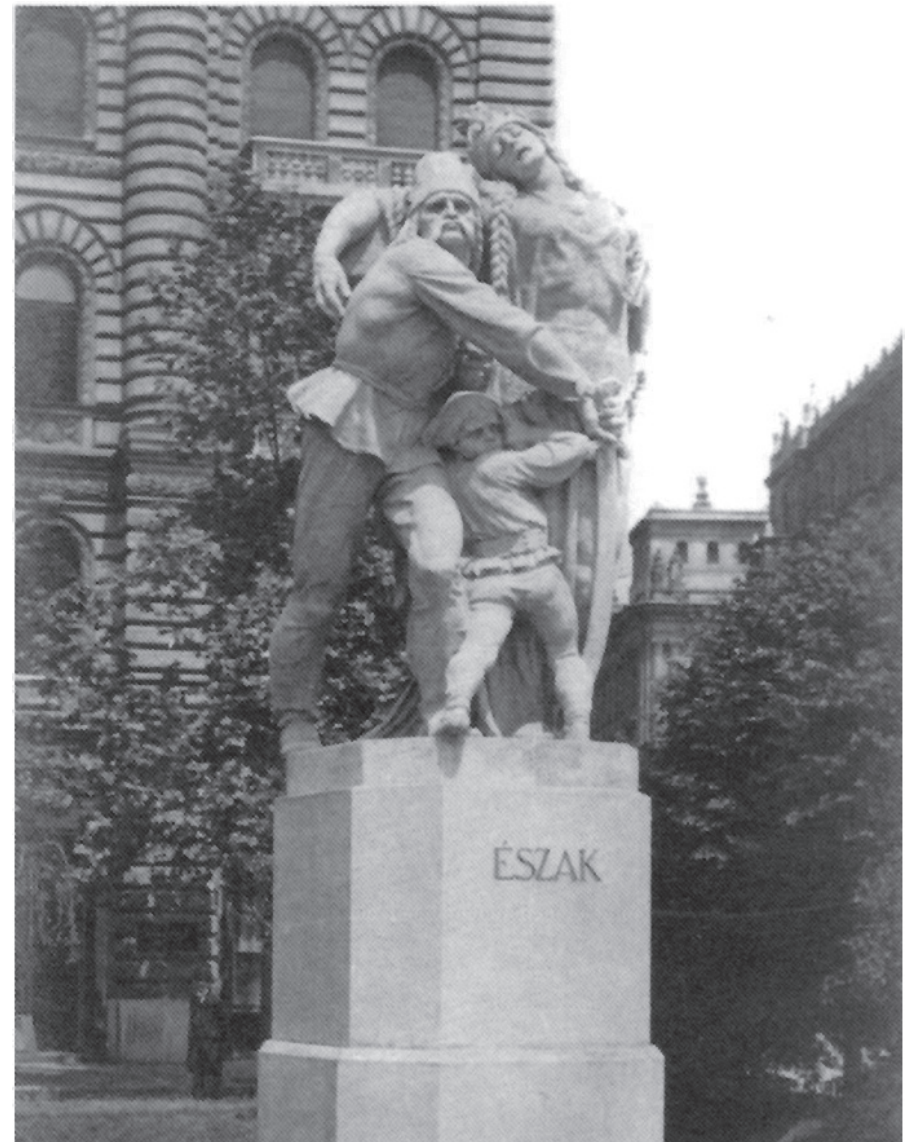

Figure 2. The monument depicting a Magyar 'Kuruc' warrior protecting the Slovak child.

1 Thanks to Mr. Milan Straka for the picture and associated research. 
The image of a Magyar 'Kuruc' warrior protecting the Slovak child is not necessarily as surprising as it may at first seem; many ethnically Slovak peasants joined the 'Kuruc' armies at the time. But it is the shameless appropriation of memory here which is shocking. The monument—unwittingly—captures a key element of the Slovak iconography of memory: the collection and deportation of Slovak children to far-off Magyar orphanages for re-education. For it to be commemorated here so publicly is a curious acknowledgement of the children of Slovakia, perhaps a subliminal recognition of past events. A proverb that was once current in Hungary is: "Vagyok is, nem is, mint a tót gyerek". It is included in a dictionary published to celebrate Magyar culture in the Millennium year of 1896. It translates as: "I am and I am not—just like Slovak children" (the actual word used here for a Slovak is tót, a pejorative term). This long-lost proverb gives a certain amount of credence to the stories of the disappeared Slovak children. The statue implies that the Slovak is bereft without the Magyar and that the true mother of the Slovaks is the allegorical figure of Hungária herself, statues of whom began to be erected across Hungary following the loss of the 1848/49 revolution and War of Independence against the Austrian Habsburgs.

With regard to the officially published Hungarian education policy the Magyar 'Kindergarten Act', or Kisdedóvó törvény, was passed in 1891. This is the current (2018) valid view of that Act as recorded in an official OECD (Organisation for Economic Co-operation and Development) document (OECD, 2004):

\section{History of kindergarten in Hungary}

43. Hungary developed early care and education at much the same time as the rest of Europe. As early as 1806 it was possible for children from the age of 6 years to attend school. The first official kindergarten was established in Hungary in 1828 and was the first kindergarten in Central Europe. Through the first half of the $19^{\text {th }}$ century kindergartens were operated as pre-school institutions with a strong emphasis on education with only a secondary emphasis on play. In 1891, the Kindergarten Act (Kisdedóvó törvény), shifted the emphasis more toward the development of the whole child with a lower emphasis on cognitive development in isolation from other aspects of development.

This OECD record is disturbing. The curious Internet visitor seeking information on the history of education in Hungary, and working in the English language only, would feel justified in trusting the accuracy and objectivity of the entry provided in the report. No effort is made in the report to explore the cultural context of the entry. In its acknowledgements section the report states that, "The OECD wishes to thank the Hungarian Ministry of Education and the Hungarian Ministry of Health, Social and Family Affairs" (OECD, 2004) and 
with these words both washes its hands of objectivity and, further, reveals a complete lack of contextualisation of educational issues in the murky ethnic waters of this other Europe.

\section{Blurred visions}

The 1911 edition of the Encyclopaedia Britannica has the following reference to this Act, a reference which sheds a little more light on the topic, but not much:

In Hungary a law was passed in 1891 providing for the education and care of children between three and six, either by asyle or nurseries open all the year round ... (Encyclopedia Britannica, 1911)

What is interesting here is the use of the archaism 'asyle'. According to the OED the word 'asyle' is an earlier form of the word 'asylum'. The definitions of the meanings of the word are as follows:

1. A sanctuary or inviolable place of refuge and protection for criminals and debtors, from which they cannot be forcibly removed without sacrilege.

2. A secure place of refuge, shelter, or retreat.

3. Inviolable shelter; refuge, protection.

We can disregard the first definition as the Slovak children were not voluntarily seeking sanctuary; they were in fact victims of kidnap. So, in our context the term has the sense of the Magyar authorities placing Slovak children under the protection and shelter of the Magyar authorities. Hungarian MP, Béla Grünwald likened the role of the schools in the Kingdom of Hungary to the role of mills in the production of flour, taking them in as 'raw' "children of non-Magyar nationality" and producing 'processed' "conscious Hungarian patriots" out of them (Mannová, 2000, p. 224).

Grünwald himself is an interesting example of the phenomenon; he was the son of a Magyarized German farm steward father and a Slovak mother. The Magyars had in him a perfect champion of the Magyar cause: "Származása ellenére nem jelentett számára problémát a szlovák nemzetiségi mozgalommal szembeni fellépés" ('In spite of his origins it wasn't difficult for him to oppose the Slovak nationality movement'; Ablonczy, 2000), and his name became famous throughout Hungary. It was synonymous with the closing down in April 1875 of the Slovak 
gymnasia (grammar schools) and the cultural organisation Matica slovenská, and consequently the name for this kind of activity against the minority nationalities henceforth became "grünwaldizmus". But the thinking behind his aim is also of interest, especially the use of the French republican model, as explained here:

Grünwald elképzelése szerint a szlovák tömegeket nem volt szükséges magyarositani, olyasféleképpen kellene kiszakitani öket a szlávság testéböl, ahogy a német ajkú elzásziak is hüséges állampolgárai lettek Franciaországnak. Ez a program - végrehajtása esetén - döntö fölénybe juttatta volna az akkor tizenhárommilliós Magyarország hétmilliós magyarságát a nemzetiségekkel szemben.

[According to Grünwald's idea it wasn't necessary to Magyarize the Slovak masses, instead they should be torn out of the Slavic body in the same way as the German-speaking Alsatians became loyal citizens of France. If this policy had been successfully implemented, it could have created a decisive superiority for the seven million Magyars over the national minorities in the then thirteen million-strong [Kingdom of] Hungary.] (Ablonczy, 2000)

Yet the Magyars couched their activities in an aura of caring for the individual, and this is what has come through unmediated into the recent and still current OECD document. The OECD report thus gives further credence to the distorted notion of Magyar liberalism in the late nineteenth century. The plaque in Bratislava goes some way to right the wrong and redress the balance, and is not reticent in its use of language. The key elements of the plaque are: the quantities of children involved; that they were deported; the deliberateness ('purposively' in the English text of the plaque); and that they were 'denationalized'. The last phrase is strange, here meaning to deprive somebody of their proper nationality, though it is rarely used. This plaque stands as a testament to a sinister aspect of the ethnic bullying policy of Magyarization; the bullying has been increased and now extends to kidnapping.

This is a catch-all law which is almost above the law because it is the law; any child could fit into one of these categories on the whim of the authorities, and it is this lack of transparent accountability which undermines any implied guiding moral principles the Magyars may have been attempting to apply. In essence this law legalises the removal of any child anywhere into the care of the state orphanages of majority Magyar areas. 


\section{Shared and contested realities}

A study of overlapping culture in Hungary and Slovakia leads us into a deferred reality of sharedness; by observing and studying the attempts on the Slovak side to establish a distinct, discrete cultural identity we acknowledge the urge to self-expression that was stunted and suffocated by overt and pointless attempts at aggressive Magyar cultural-linguistic-educational imperialism. The Slovak word for this is instantly recognised by everybody in Slovakia: madarizácia; pomad'arčovanie can also be used; the phrase pomad'arit v̌setky národy uhorskej, 'to Magyarize all the peoples of Hungary', is particularly well known. In Hungary the words magyarositás / magyarositani, 'Magyarization / to Magyarize', and magyarosodás / magyarosodni, 'Magyarification / to Magyarify (to gradually Magyarize)' are rather unknown concepts. The word remains untaught and unknown in Hungarian schools today. Because Magyarization was carried out as a detrimental policy against the Slovaks it is the Slovaks who preserve the memory of it, it is one of their key 'nodes of memory' and a raison d'être and rationale for Slovak existence.

To the Magyar it is a natural given for the Magyar to be master of the Carpathian Basin, reinvigorating the corrosive corpse of Magyar hegemony and ethnic superiority across the region.

The reform-minded 'Greatest Hungarian', Count István Széchenyi, famously declared in 1833 that nyelvében él a nemzet: a nation lives through its language (or, more eloquently in English: "A nation is only alive through its own language"), watchwords that are as powerful and emotive to the Magyar today as in the linguistically-challenged past.

Brutality is explicit in and implicit to the colonial narrative. Compliance with the colonial diktat is expected unconditionally; giving the Slovaks the Magyar tongue is as a gift to them, equivalent to giving the Slovak 'savage' the means to access the civilization that they inherently lack. It means, put simply, civilizing them through education. The non-Magyar is the 'other' and they understand force, violence and pain most readily because they are primitive, and because they are primitive they are the colonial other, the non-us who deserve to be ruled by $u s$. It is the simplistic narrative of ruler and ruled. In the mind of the Magyar, resistance is a malfunction. The Magyars were widely seen as despots: 


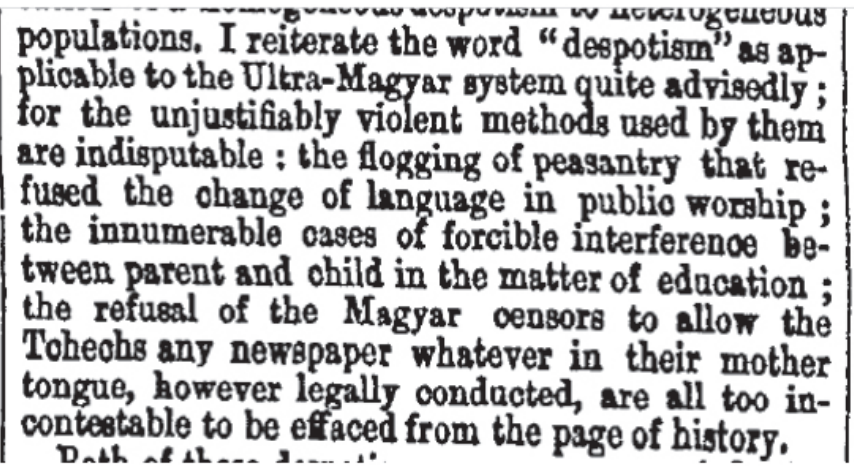

(The Times, 1849)

In 1879, William R Morfill, an English Slavonic languages scholar and later an Oxford University professor commented: "How long this small nationality [of Slovaks] will be able to resist Magyarization is doubtful" 2 . The policy of Magyarization had caused a consistent decline in the numbers of Slovaks in the towns of the Felvidék (the old Magyar name for today's Slovakia) with a corresponding increase in the numbers of Hungarian speakers: "in schools, offices, cafes, societies and the corso, people spoke exclusively in Hungarian”(Lipták, 2002 , p. 14). People's names, shop names, and village names had been increasingly Magyarized before 1918 and the Magyar tongue was rapidly becoming the demotic urban tongue. Slovak historian Lubomír Lipták points to this as a key period which had a profound effect on post-colonial Slovak society as it actually initiated and established an anti-minority policy in Slovakia (and by extension in the rest of Hungary) which became rooted as an anti-minority tradition where national minorities were seen as dangerous, disloyal elements of society. This tradition is still active in Hungary and Slovakia today.

Resistance to absorption by assimilation into the majority culture was and still is seen as unpatriotic at least and treason at worst. István Bibó comments that this seemed to be the eternal fate of the different nationalities in this part of Europe: "e terület melegágya mindenféle zürzavaros, homályos és hazug politikai filozófiának" ('this territory is a hotbed for all kinds of muddled, obscure and lying political philosophies'; Bibó, 1945-1949). By 1917, no secondary school in the territory of Slovakia used either Slovak or German ${ }^{3}$ as the language of instruction, only

\footnotetext{
See the entry for 'Magyarization' in OED, 1989.

3 There was a significant German community in the Kingdom of Hungary, and in the territory of Slovakia they are known as Karpatendeutsche. There are around 5,000 left today. See http:// ec.europa.eu/
} 
Hungarian was used. Lipták describes the situation in Slovakia between 1867 and 1918 with regard to national minorities as "unbalanced stability" (Lipták, 2002, p. 17), in that he sees the Magyar rule over the Slovaks as a pretence, a kind of house of cards where the Magyar system is a system of great lies.

\section{Western perceptions}

This is precisely what Robert William Seton-Watson (1879-1951), writing under the pseudonym Scotus Viator, felt when he first visited Hungary in 1905-1906, stung by the blatant duplicity of the Magyars:

The Magyars, he explained, had 'lied' to him. Exactly how they had disillusioned him was not quite clear. His apparent timidity, abundant good faith, and eager simplicity may have tempted them to overload his mind with assurances which would not bear investigation. The trouble was that he did investigate them ... (ODNB, n.d.)

After this he commented bitterly: "And so I went home with all my ideas completely bouleversées by the varied experiences of these nine months" (SetonWatson \& Seton-Watson, 1981). Seton-Watson was passionate about the Slovaks. He quickly saw through the smokescreen of the Magyars during his first visit to Hungary. When he arrived he believed that fin de siècle Hungary was a sturdy nation pulling itself up by the bootstraps after years of Austrian oppression and handing out the most liberal language and education laws in Europe, granting unimagined rights and privileges to her minorities. Seton-Watson devoted his life and much of his personal wealth to the promotion of minority rights in the eastern part of Europe. He had been particularly influenced by Anton Štefanek, whom he had met in Vienna. Štefanek was later to become a professor and politician in Czecho-Slovakia; he and Seton-Watson corresponded from 1906 to 1939. Of his first meeting with Štefanek, Seton-Watson wrote: "We adjourned to a neighbouring café and talked for hours. I soon realized how completely I had neglected the Slovak aspect of the general problem" (Seton-Watson \& SetonWatson, 1981).

The nadir of Magyar policies towards the Slovaks was the massacre at Csernova which was to signal the beginnings or perhaps culmination of the increasingly desperate and violent death throes of the Magyars' Kingdom of Hungary, which had long been sick and flying in the face of destiny. The Csernova massacre, 
though almost completely unknown in today's Hungary, marks the start of the bloody unravelling of over 1,000 years of Magyar domination in the Carpathian Basin, and the bitterest Magyar denouement. Csernova is the end result of many years of constant, rampant, unbridled, hysterical Magyarization policies towards the Slovak minority, a nation of whom Magyars would perhaps still infamously say: tót nem ember ('Slovaks are not human').



\section{-Černouská massakra.}

V Cernovej, obei liptovskej, liala sa stovenská kri potokiußi. Deiarłe zandírskyeh guliek

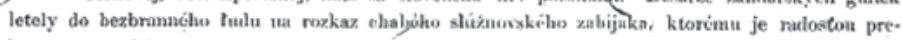
lievat nesinnú 'krs! -

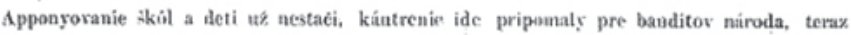

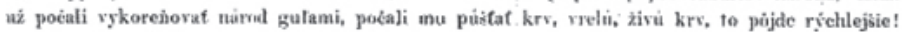
A cirkev im podala ruku, kñaxi vtrhli do obce, aby ju pokerili!!

V Cernovej vystavili si kostol, najviac starostou, pilnostou a horlivostou rużomberskébo su. spendorancho farira Androja Hlinku. S posvisckou etiecli potkat, az bude Hlinka nazad uredený do úradu. Církevuá vrehnost ćakat necheela a ustanovila posvātit nový ehrárn vèera, $r$ uedelu, 2T. oktobra. Ta poslsla kñazov pod brachiumom santarsksm. Lud nechcel pustit knazov

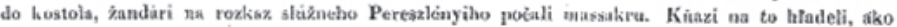



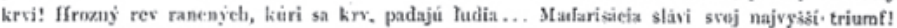

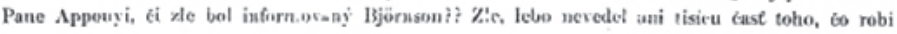

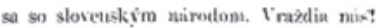

DTa informovania stalo sa tak: Lnd shromazdil sa pred dedinou a nechcel pustif koce, na ktorỵ́ch boli kñazi a slúžny.

Va to kàzal wiùn. Pereszlényi striefat. 12 žandari dall salvu do Fudu na s krokov, vystrelill 56 ráz, פ boll hned mrtvi, 3 skoro umrell a 25 sú tazk raneni.

Medzi mítvymi a tažko ranenými sú žeuy, mladé devy a mužovia. Jedna maf, majúca seden: deti. Gulc iśly najviate do prix a brueha. Bolo to zabijanie Iudi na rozkaz slúźncho. 


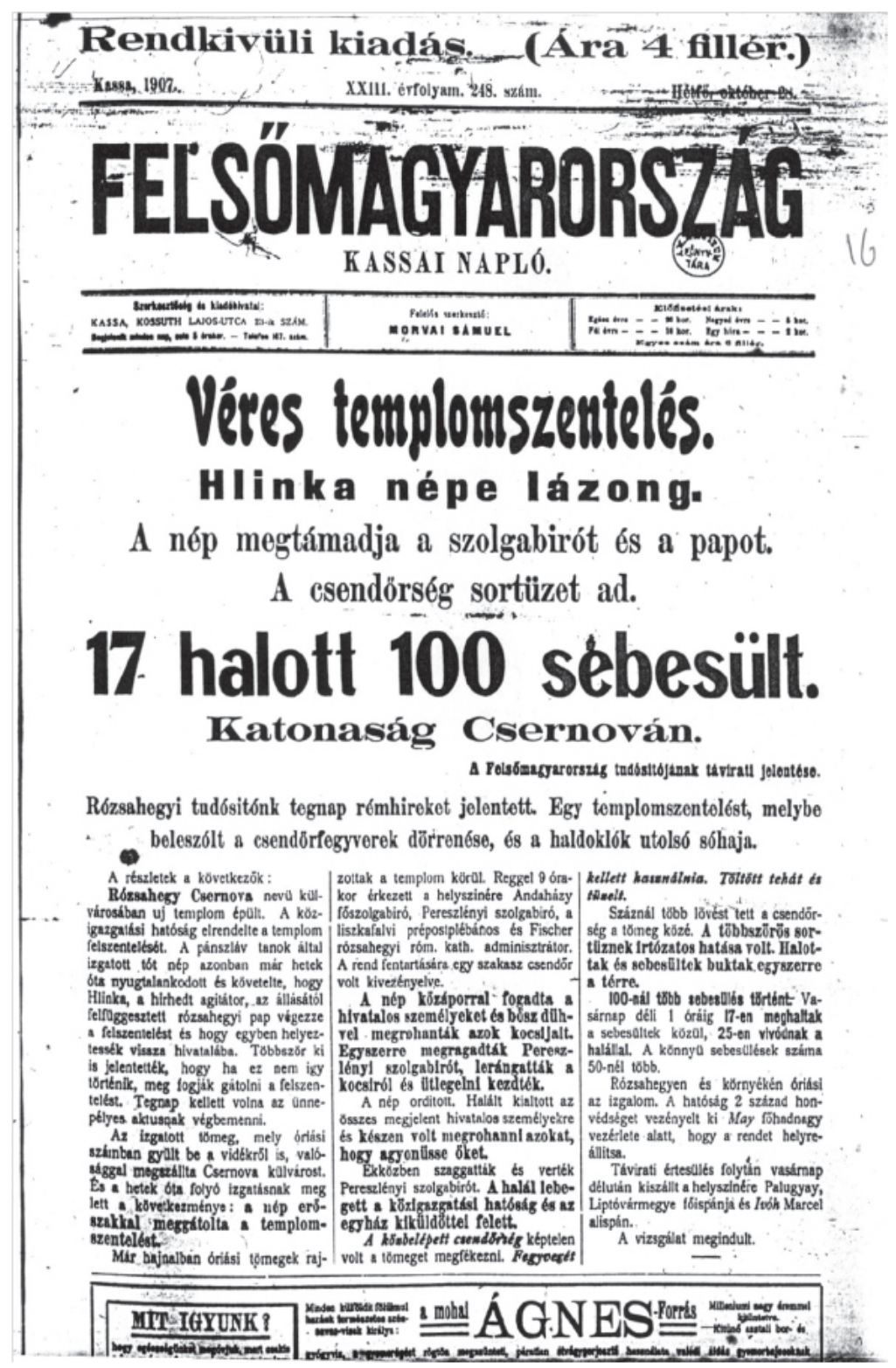




\section{Bibliography}

Ablonczy, B. (2000), 'Harc a Magyar felvidékért,' Europai utas, vol. 14, no. 1, p. 40. Retrieved from http://hhrf.org/europaiutas/20003/22.htm [accessed 20 Jul 2017]

Baranyai, Z., ed. (1947), Hungary at the Paris Peace Conference, Papers \& documents relating to the Czechoslovak draft amendment concerning the transfer of 200,000 Hungarians from Czechoslovakia to Hungary, Budapest: Hungarian Ministry for Foreign Affairs, University Press.

Bethlen, S. (1934), The Treaty of Trianon \& European Peace, London: Longmans, Green $\&$ Co.

Bibó, I. (1945-1949), Az európai egyensúlyról és békéröl. Retrieved from http://mek.oszk. hu/02000/02043/html/60.html [accessed 20 Jun 2017]

Encyclopaedia Britannica (1911), 'Hungarian nursery', Online 1911 Encyclopedia Britannica. Retrieved from http://www.1911encyclopedia.org/Infant_Schools [accessed 31 Dec 2017]

Hansard (1908), 'Csernova and Slovak riots,' HC Deb 02 April 1908, vol. 187, cc670-1.

Lipták, L. (2002), Changes of Changes: Society and Politics in Slovakia in the 20th Century, Bratislava: Academic Electronic Press, Historický ústav SAV.

Mannová, E., ed. (2000), A Concise History of Slovakia, Bratislava: Academic Electronic Press.

McCrone, D. (1998), The Sociology of Nationalism. Tomorrow's Ancestors, London: Routledge. https://doi.org/10.4324/9780203428856

Mikszáth, K. (1882), Cikkek és karcolatok II, p. 399. Retrieved from http://mek.oszk. hu/00900/00901/html/08.htm [accessed 30 Apr 2017]

Náray, A. (2016), 'Nyelvében él a nemzet. A nyelv szerepe az identitásunkban,' Hetek, 25 November 2016. Retrieved from http://www.hetek.hu/eletmod/201611/nyelveben el_a_nemzet [accessed 20 Jun 2017]

ODNB (n.d.), Oxford Dictionary of National Biography. Retrieved from http://www. oxforddnb.com/ [accessed 31 Dec 2017]

OECD (2004), Country Note for Hungary, Early Childhood Education and Care Policy. Retrieved from http://www.oecd.org/dataoecd/51/20/34425201.pdf [accessed 31 Dec 2017]

OED (1989), Oxford English Dictionary, 2nd ed. online. Retrieved from http://www. oed.com/ [accessed multiple times]

Scotus Viator (1908), 'Appendix XXI: The Defence of Father Hlinka before the Court of Pressburg (4 May 1908),' in Racial Problems in Hungary, London: Archibald Constable \& Co.

Seton-Watson, H. \& Seton-Watson, C. (1981), The Making of a New Europe: R. W. Seton-Watson \& the Last Years of Austria-Hungary, London: Methuen. 
Seton-Watson, R. W. (1908), Political Persecution in Hungary: An Appeal to British Public Opinion, London: Archibald Constable \& Co.

The Hungarian Quarterly (n.d.), [Home page]. Retrieved from www.hungarianquarterly. com/ [accessed 31 Dec 2017]

The Times (1849), 23 August, The Times Digital Archive. Retrieved from https://www. gale.com/uk/c/the-times-digital-archive [accessed multiple times] 